\title{
A cross sectional study to find out the efficacy of prevention of parent to child transmission services providing centers of Indore division
}

\author{
Chakresh Jain*, A. K. Khatri, Veena Yesikar, Sanjay Dixit, Shailesh Rai
}

Department of Community Medicine, MGM Medical College, Indore, Madhya Pradesh, India

Received: 19 May 2016

Accepted: 24 May 2016

*Correspondence:

Dr. Chakresh Jain,

E-mail: drchakreshjain81@gmail.com

Copyright: (C) the author(s), publisher and licensee Medip Academy. This is an open-access article distributed under the terms of the Creative Commons Attribution Non-Commercial License, which permits unrestricted non-commercial use, distribution, and reproduction in any medium, provided the original work is properly cited.

\section{ABSTRACT}

Background: The HIV and AIDS epidemic is not just a public health concern, but a major socio-economic problem in India as it is in other parts of the world. In India PPTCT interventions under NACP was started in2002, using single dose NVP prophylaxis For HIV positive pregnant women during labour \& also for her new born child immediately after birth. The objective of the study was to find out the proportion of HIV among ANC registered \& the efficacy of PPTCT by determining seroconversion rate in children born to HIV positive mothers during study period.

Methods: All PPTCT Services providing centres located in four districts of Indore division were taken in study. The required information (data of $1^{\text {st }}$ January to $31^{\text {st }}$ December 2014) was collected through pre-designed semi structured questionnaire undertaken nodal in charge, counselling staff/ laboratory technicians of each centre during the study period of January to October 2015. The data collected was entered into Microsoft excel spread sheet and analysis was done by SPSS.

Results: The number of HIV positive registered ANC cases \& positivity rate among them, both were highest at medical college level as they are catering highest numbers of ANC OPDs \& referral too while it is lowest at CHCs level. Among total 67 positive pregnant women, two babies died before 6 weeks. Out of 65 babies tested \& 2(3\%) babies were found positive.

Conclusions: There has been an improvement in number of pregnant women undergoing HIV testing with appropriate pre-test \& post-test counselling over years but ANC load in hospitals of urban areas, were higher in comparison to rural, so up gradations of hospitals at primary level should be done.

Keywords: HIV, ANC, PPTCT, Seroconversion

\section{INTRODUCTION}

The HIV and AIDS epidemic is not just a public health concern, but a major socio-economic problem in India as it is in other parts of the world.

Cuba today became the first country in the world to receive validation from $\mathrm{WHO}$ that it has eliminated mother-to-child transmission of HIV and syphilis. "Eliminating transmission of a virus is one of the greatest public health achievements possible," said Dr. Margaret
Chan, WHO Director-General. ${ }^{1}$ WHO reports in the World Health Report 2002, that of the 35 million healthcare workers, 2 million experience percutaneous exposure to infectious diseases each year. It further notes that $37.6 \%$ of Hepatitis B, 39\% of Hepatitis C and $4.4 \%$ of HIV/AIDS in Health-Care Workers around the world are due to needlestick injuries. ${ }^{2}$ The distribution and spread of the disease in India is highly uneven. Although much of India has a low rate of infection, certain places have been more affected than others. HIV epidemics are more severe in the southern half of the country and the 
far north-east. The highest HIV prevalence rates are found in Andhra Pradesh, Maharashtra, Tamil Nadu and Karnataka in the south and Manipur and Nagaland in the north-east. In India, HIV/AIDS remains a major public health problem, mainly affecting people in the productive and reproductive age group of 15 to 49 years. $^{3}$

National s AIDs control programme was launched in India in the year 1987. The national strategic plan for PPTCT services using multi-drug ARVs in India was developed in May June 2013 for nationwide implementation in a phased manner. Based on the new WHO Guidelines (June 2013) and on the suggestions from the technical resources group during December 2013, department of AIDs Control has decided to initiate lifelong ART ( using triple drug regimen) for all pregnant $\&$ breast feeding women living with HIV. ${ }^{4}$

The first case of HIV/AIDS was detected in MP in 1988, and since then the number of AIDS cases is rising. In view of the seriousness of the problem, MP Government constituted AIDS control cell in 1992 under medical education department. Subsequently MP state AIDS control society was constituted on 14 July 1998. Under these programmes integrated counseling and testing centers were established at the Medical colleges and then in district hospitals of the state. With the objectives of make HIV testing facility easily available at a cheaper cost with proper pre and post-test counseling to all individuals in confidential environment, who are willing to get tested/ referred for testing by Health Care Institutions such as TB Clinic, Blood Bank, ANC Clinics \& STD Clinics. At present ICTC were also established at the Community Health Centers (CHC). At present there are 162 ICTC's \& 649 F-ICTCs in Madhya Pradesh \& HIV counselling and testing facility easily available at all the established ICTCs free of cost and in confidential manner. ${ }^{5}$

A study conducted by Deoki Nandan, K S Nair et al in 2013 in Mysore District; Karnataka concluded that, to achieve the universal coverage of PPTCT services, providers should ensure that all pregnant women access PPTCT services. ${ }^{6}$ In a study Darak et al found that lack of knowledge about the availability of HIV testing facilities among women and fear of stigmatization from health providers seem the most important barriers in accessing counselling and HIV testing services. ${ }^{7}$ It did not take long for people to realize that this disease could also be heterosexually transmitted when the virus was found passed to women as well. ${ }^{8}$ UNAIDS states that mother to child transmission (MTCT) is the largest source of HIV infection in children below the age of 15 years. ${ }^{9}$ Government of India is committed to work towards achievement of the global target of "elimination of new HIV infections among children" by $2015^{10}$

\section{Aims and objectives}

To find out the proportion of HIV among ANC registered $\&$ the efficacy of PPTCT by determining seroconversion rate in children born to HIV positive mothers during study period.

\section{METHODS}

The present study was a cross- sectional study \& conducted keeping in consideration the original guidelines issued by the National AIDS Control Organization (NACO) for the Integrated Counselling and Testing Centers \& Updated guidelines for Prevention of Parent to Child Transmission (PPTCT) of HIV using Multi Drug Anti-retroviral Regimen in India December, 2013. For selecting four districts of division, map of all districts of Indore division was divided in four quadrants and one district of each quadrant was chosen to study. Hence all PPTCT Services providing centres/ICTCs centres located in four districts Indore, Barwani, Jhabua, \& Burhanpur was enlisted. Total 19 (100\%) centres were thus included for the study purpose. Nodal in charge, counsellor and Laboratory Technicians of the respective ICTC were interviewed. The required information (data of 1st Jan to 31st Dec 2014) was collected through predesigned semi structured questionnaire undertaken nodal in charge, counselling staff/laboratory technicians of each centre during the study period of January to October 2015. The data collected was entered into Microsoft Excel spreadsheet and analysis was done by SPSS.

\section{RESULTS}

HIV Positivity rate among ANCs registered were highest at medical college and lowest in CHCs. A significant difference in HIV positivity rates was observed at different levels of health care.

Table 1: HIV Positivity rate among ANC at various levels of health care.

\begin{tabular}{|llll|}
$\begin{array}{l}\text { Name of } \\
\text { Centre }\end{array}$ & $\begin{array}{l}\text { Total } \\
\text { ANC in } \\
\mathbf{2 0 1 4}\end{array}$ & $\begin{array}{l}\text { HIV } \\
\text { positive } \\
\text { Mother }\end{array}$ & $\begin{array}{l}\text { Positivity per } \\
\text { thousand } \\
\text { ANC }\end{array}$ \\
\hline Medical colleges & 17838 & 38 & 2.13 \\
\hline District hospitals & 20015 & 21 & 1.05 \\
\hline Urban hospitals & 16119 & 11 & 0.68 \\
\hline CHCs & 10074 & 5 & 0.496 \\
\hline Total & 64046 & 75 & 1.17 \\
\hline
\end{tabular}

*P value was 0.0001

HIV Positivity rate per thousand ANC among districts is highest at Indore district because ANCs registered at Indore which was thrice of sum of other three districts alone. It is lowest at district Jhabua, which caters one tenth population of Indore district. Chi-square test applied $\&$ p-value is 0.547 which was not significant (Table 1 , Figure 1). 


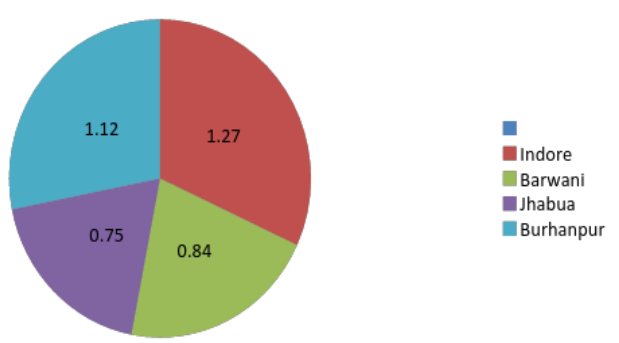

Figure 1: HIV positivity per thousand $\mathrm{ANC}$ at the study districts.

Among 67 positive pregnant women, two babies died before 6 weeks and 65 underwent testing and 2 (3\%) babies were found positive (Table 2).
Among 36 deliveries conducted in the Medical Colleges, 2 babies of MYH hospital died before 6 weeks and 34 babies were nonreactive (Table 2).

Out of 18 deliveries conducted in district hospitals, one baby at District hospital Indore was positive. The baby was reactive as mother had stopped ART \& continued breast feeding (Table 2).

Out of 9 deliveries conducted in urban hospitals one baby of Hukumchand hospital was found reactive as her mother had stopped ART \& continued breast feeding (Table 2).

Table 2: Number of Positive children born to HIV positive mothers.

\begin{tabular}{|lllll|}
\hline Centers & $\begin{array}{l}\text { Delivery } \\
\text { conducted } \\
\text { n(\%) }\end{array}$ & $\begin{array}{l}\text { Total baby tested for } \\
\text { HIV } \\
\text { n }(\%)\end{array}$ & $\begin{array}{l}\text { Reactive DBS/ } \\
\text { Antibody test } \\
\text { n (\%) }\end{array}$ & $\begin{array}{l}\text { Nonreactive DBS/ } \\
\text { antibody test } \\
\text { n }(\%)\end{array}$ \\
\hline Medical colleges & 36 & $34(100)$ & $0(0)$ & $34(100)$ \\
\hline District hospitals & 18 & $18(100)$ & $1(5)$ & $17(95)$ \\
\hline Urban hospitals & 9 & $9(100)$ & $1(11)$ & $8(89)$ \\
\hline CHCs & 4 & $4(100)$ & $0(0)$ & $4(100)$ \\
\hline Total & 67 & $65(100)$ & $2(3)$ & $63(97)$ \\
\hline
\end{tabular}

Table 3: Status of breast feeding among HIV positive mothers.

\begin{tabular}{|c|c|c|c|c|c|c|}
\hline Centers & $\begin{array}{l}\text { Breast feeding } \\
\text { n }(\%)\end{array}$ & $\begin{array}{l}\text { Replacement } \\
\text { feeding } \mathbf{n}(\%)\end{array}$ & $\begin{array}{l}\text { Mixed } \\
\text { feeding n (\%) }\end{array}$ & $\begin{array}{l}\text { Status unknown/ } \\
\text { baby death n (\%) }\end{array}$ & $\begin{array}{l}\text { HIV positive } \\
\text { babies n }(\%)\end{array}$ & $\begin{array}{l}\text { Total live } \\
\text { birth }\end{array}$ \\
\hline $\begin{array}{l}\text { Medical } \\
\text { colleges }\end{array}$ & $26(72)$ & $2(6)$ & $2(6)$ & $6(16)$ & 0 & $36(100)$ \\
\hline $\begin{array}{l}\text { District } \\
\text { hospitals }\end{array}$ & $15(83)$ & $0(0)$ & $2(11)$ & $1(6)$ & $1(6)$ & $18(100)$ \\
\hline $\begin{array}{l}\text { Urban } \\
\text { hospitals }\end{array}$ & $5(56)$ & $0(0)$ & $2(22)$ & $2(22)$ & $1(11)$ & $9(100)$ \\
\hline $\mathrm{CHCs}$ & $4(100)$ & $0(0)$ & $0(0)$ & $0(0)$ & $0(0)$ & $4(100)$ \\
\hline Total & $50(75)$ & $2(3)$ & $6(9)$ & $9(13)$ & $0(0)$ & $67(100)$ \\
\hline
\end{tabular}

Table 4: Seroconversion rate at various levels.

\begin{tabular}{|lllll|}
\hline Centers & Delivery conducted & $\begin{array}{l}\text { Total baby } \\
\text { tested for HIV }\end{array}$ & Reactive DBS/ antibody & \% Seroconversion \\
\hline Medical colleges & 36 & 34 & 0 & 0 \\
\hline District hospitals & 18 & 18 & 1 & 5.6 \\
\hline Urban hospitals & 9 & 9 & 1 & 11.1 \\
\hline CHCs & 4 & 4 & 0 & 0 \\
\hline Total & 67 & 65 & 2 & 3.07 \\
\hline
\end{tabular}

Out of 36 deliveries conducted in the Medical Colleges, 2 babies of MYH hospital died before 6 weeks \& the status of breast feeding of 4 babies were unknown to the counsellor. Among District hospitals, the status of breast feeding of 1 baby was unknown at District hospital Indore. One ANC at District hospital Indore was LFU from ART \& continued breast feeding and hence her baby was detected reactive on antibody test. 
Out of 9 deliveries conducted at urban hospital status of breast feeding of 2 babies of Mangilal Churiya hospital was unknown (Table 3).

Among Urban hospitals, one ANC of Hukumchand hospital was LFU from ART. All 4 babies of CHCs were breast fed. Out of total 67 deliveries conducted 50 (75\%) babies were on exclusive breast feeding (Table 3 ).

Overall seroconversion rate in Indore division was $3.07 \%$. Seroconversion of HIV positive mother was nil at all Medical Colleges \& CHCs while it was highest at the level of urban hospitals (Table 4).

\section{DISCUSSION}

In the present study of Indore division 64046 women were referred to ICTC from various ANC clinics, $59941(93 \%)$ were counselled \& tested. Out of them 75 HIV positive ANCs were found \& HIV positivity rate was $0.13 \%$. Although over the years, government has made it mandatory for every pregnant woman to check her HIV status \& implemented, still pregnant women are not utilizing ICTC services. Dr A. Sinha \& M. Roy et al conducted a study in 19 medical colleges of India to examine the functioning of the PPTCT service delivery during the year 2005-2006, found 78\% women were undergoing HIV testing and $52.7 \%$ received ART prophylaxis during delivery. ${ }^{11}$ Sukanta Mandal et al conducted a study in a Rural Tertiary Care Hospital of West Bengal, from 2004-2008, reported that a total of 40,140 pregnant women were registered and out of total 23,812 pregnant women counselled, 19,794 individuals $(83.13 \%)$ agreed for HIV testing and 111 pregnant women were found to be HIV positive. ${ }^{12} \mathrm{M}$ Dash, S Padhi et al did a study in Berhampur, Orissa from November 2005-April 2008 found that 4560 (64.53\%) were tested out of 7066 antenatal care (ANC) patients counselled for PPTCT. ${ }^{13}$ They found 47 (1.03\%) HIV positive women among tested. Shuvankar Mukherjee et al in year 2009-10, did a study to evaluate the PPTCT services in West Bengal. ${ }^{14}$ 2, 88,746 Cases were counselled, 2, 69,471 Cases were tested for HIV \& 375 $(0.14 \%)$ Cases were detected HIV positive.

This shows that over the year's rate of pregnant women undergoing counseling for HIV \& HIV testing following pretest counselling has increased. In the present study conducted in Indore division, out of 75 HIV positive ANCs detected, 5 lost to follow up. One ANC died during her pregnancy \& two of them aborted. We found $6.7 \%$ dropouts among all HIV positive registered \& remaining $93.3 \%$ of HIV positive ANCs received ART prophylaxis. Among 67 deliveries conducted, 16 (24\%) deliveries were conducted by caesarean section and all the babies received Nevirapine prophylaxis. Out of 67 children born to HIV positive mothers 2 children were found Reactive. The mothers of these 2 children were loss to follow up (LFU) from ART centre \& continued to breastfeed. Thus ARV prophylaxis helped to reduce the viral load of the mothers and eventually reduced the transmission of the virus from mother to child. Goswami Sebanti et al in Kolkata from 2004 to 2007 conducted a study \& found Out of the 95 live births, only 46 babies were tested out of which only one was reactive \& 45 were non-reactive. ${ }^{15}$ Similarly S. Parameshwari et al in Namakkal PPTCT Center of Chennai, found that over a period of five years 56 antenatal women tested positive, $47(83 \%)$ of them received Nevirapine and Nine were lost to follow up. ${ }^{16}$ This shows that acceptance of PPTCT Services have improved over the years. The pregnant women are coming forward \& utilizing the services reducing the transmission of the virus which is a good trend. Thus ARV prophylaxis helped to reduce the viral load of the mothers and eventually reduced the transmission of the virus from mother to child.

In present study, out of 67 deliveries conducted, $50(75 \%)$ babies were on exclusive breast feeding, $6(9 \%)$ were on mixed feeding \& only $2(3 \%)$ were on replacement feeding. 2 babies turned HIV reactive when their mother stopped ART \& continued to breast feed them. Similarly Hiral H. Shah et al in Ahmedabad, in a study found $6(25 \%)$ out of 8 babies delivered were on exclusive breast feeding. ${ }^{17}$

In present study, overall HIV positivity rate in Indore division among ANCs was $0.12 \%$, Seroconversion rate found were $3.07 \%$ among HIV positive treated women. While recent data of Madhya Pradesh shows Estimated Number of Pregnant Women Needing PPTCT services is $0.01 \%(1084 / \mathrm{lakh})$ and of India is $0.35 \%$ (35255/lakh). ${ }^{18}$ In Indore Estimated Number of Pregnant Women Needing PPTCT services is $0.12 \%$ which is twelve times higher than Madhya Pradesh, as Indore is the industrial hub of Madhya Pradesh and migration of population is higher from other districts of Madhya Pradesh.

Funding: No funding sources

Conflict of interest: None declared

Ethical approval: The study was approved by the Institutional Ethics Committee

\section{REFERENCES}

1. WHO Validates Elimination of Mother-to-Child Transmission of HIV and Syphilis in Cuba By Global Research News Global Research, July 04, 2015 Cuba Solidarity Campaign 30 June 2015 available at http://www.globalresearch.ca/whovalidates-elimination-of-mother-to-childtransmission-of-hiv-and-syphilis-in-cuba. Accessed on 20 April 2016.

2. Protecting health-care workers - preventing needlestick injuries. available at http://www.who.int/_occupational_health/ topics/needinjuries/en/.

3. An overview of the spread and prevalence of HIV/AIDS in India. Available at: 
www.naco.nic.in/nacp/bss1.pdf. Accessed on 20 April 2016.

4. Park's Text Book of Preventive And Social Medicine, 23rd edition. Jabalpur: Banarsi Das Bhanot publishers; 2015:431,432.

5. MPSACS Programmes. Introduction http://www.mpsacsb.org/mpsacs- Accessed on 20 April 2016.

6. Nair KS, Piang LLK, Tiwari VK, Raj S, Nandan D. Prevention of vertical transmission of HIV in India through service integration: lessons from Mysore District, Karnataka. WHO South-East Asia J Pub Health. 2013;2(2):121-7.|

7. Darak S, Panditrao M, Parchure R, Kulkarni V, Kulkarni S, Janssen F. Systematic review of public health research on prevention of mother-to-child transmission of HIV in India with focus on provision and utilization of cascade of PMTCT services. 2012;12:320.

8. Franks EK. Prevention of Mother-to-child Transmission (PMTCT) of HIV in the Sub-Saharan Africa Region with a Focus on Uganda. Liberty University Spring 2009. available at digitalcommons.liberty.edu/cgi/viewcontent.cgi article=1096...honor. Accessed on 20 April 2016.

9. UNAIDS. Prevention of HIV transmission from mother to child. Strategic options. Available at http://www.unaids.org/html/pub/ publications/ircpub05/prevention_en_pdf.pdf. Accessed on 20 April 2016.

10. NACO Updated guidelines for Prevention of Parent to Child Transmission (PPTCT) of HIV using multi drug anti-retroviral regimen in India Dec 2013 available at www.naco.gov.in. Accessed on 20 April 2016

11. Sinha A, Roy M. An ICMR Task Force Study of Prevention of Parent to Child Transmission (PPTCT) Service Delivery in India. Indian J Public Health. 2008;52(4):200-2.
12. Mandal S, Bhattacharya RN, Chakraborty M, Pal PP, Roy SG, Mukherjee G. Evaluation of the prevention of parent to child transmission program in a rural tertiary care hospital of West Bengal, India. Indian J Community Med. 2010;35(4):491-4.

13. Dash M, Padhi S, Panda P, Pattnaik D, Parida B. PPTCT of HIV: Two and a half year experience at MKCG medical college, Berhampur, India. Indian J Med Microbiol. 2009;27(3):276-81.

14. Mukherjee S, Ghosh S, Goswami DN, Samanta A. Performance evaluation of PPTCT (Prevention of parent to child transmission of HIV) programme: An experience from West Bengal. Indian J Med Res. December 2012;136:1011-9.

15. Goswami S, Chakravorty PS. Prevention of parent to child transmission of HIV (PPTCT): an effort of 4 years in a tertiary centre. J Obstet Gynaecol India. 2011;61(4):394-8.

16. Parameshwari S, Jacob MS, Vijayakumari JJ, Shalini D, Sushi MK, Sivakumar MR. A programme on prevention of mother to child transmission of HIV at Tiruchengode taluk, Namakkal district. ndian J Community Med. 2009;34(3):261-3.

17. Shah HH, Shah BS, Deliwala KJ, Damani P. Evaluation of mother to child transmission of HIV in a tertiary care centre. National $\mathbf{J}$ Med Res. 2013;3(1):38-41.

18. India HIV estimation 2015, technical report. Available

at http://naco.gov.in/upload/2015\%20MSLNS/HSS/In dia\%20HIV\%20Estimations\%202015.pdf. Accessed on 20 April 2016.

Cite this article as: Jain C, Khatri AK, Yesikar V, Dixit S, RaiK S. A cross sectional study to find out the efficacy of prevention of parent to child transmission services providing centers of Indore division. Int $\mathrm{J}$ Community Med Public Health 2016;3:1404-8. 